\title{
Experiencing a sense of calling: The influence of meaningful work on teachers' work attitudes
}

\author{
Authors: \\ Marietjie Willemse \\ Elmari Deacon ${ }^{1}$ \\ Affiliations: \\ ${ }^{1}$ Optentia Research \\ Programme, North-West \\ University, Vaal Triangle \\ Campus, South Africa \\ Correspondence to: \\ Elmari Deacon \\ Email: \\ elmari.deacon@nwu.ac.za \\ Postal address: \\ PO Box 1174, Vanderbijlpark \\ 1900, South Africa \\ Dates: \\ Received: 25 Mar. 2015 \\ Accepted: 26 July 2015 \\ Published: 4 Sept. 2015 \\ How to cite this article: \\ Willemse M., \& Deacon E. \\ (2015). Experiencing a sense \\ of calling: The influence of \\ meaningful work on teachers \\ work attitudes. SA Journal \\ of Industrial Psychology/SA \\ Tydskrif vir Bedryfsielkunde, \\ 41(1), Art. \#1274, 9 pages. \\ http://dx.doi.org/10.4102/ \\ sajip.v41i1.1274

\section{Copyright:} \\ (C) 2015. The Authors. \\ Licensee: AOSIS \\ OpenJournals. This work is \\ licensed under the Creative \\ Commons Attribution \\ License.
}

Read online:
Orientation: Worldwide transformation and change in education has placed increased demands on teachers, which has resulted in teachers experiencing a potentially negative work attitude.

Research purpose: The aim of this article was to expand the understanding of the relationship between a sense of calling, work attitude and meaningful work.

Motivation for the study: The international community has rated the quality of education in South Africa as being substandard. Therefore, work attitudes and the impact of meaningful work in the current educational system was investigated.

Research approach, design and method: A quantitative, cross-sectional survey was used with a representative sample of teachers in South Africa $(N=270)$. Data were gathered by means of questionnaires and analysed through structural equation modelling.

Main findings: A significant positive relationship was found between a sense of calling and work attitude. Meaningful work was found to mediate the relationship between a sense of calling and positive work attitude.

Practical/managerial implications: Retention of teachers displaying a positive work attitude as well as those finding meaning in their work is paramount. Communication pertaining to the broader mission and common goals of the Department of Education should transpire. Support and training should be provided and teachers should be allowed autonomy in a school atmosphere that is pleasant and disciplined.

Contribution/value-add: Sufficient support to enhance meaningful work may contribute to the delivery of quality education.

\section{Introduction}

South Africa finds itself in the midst of an educational crisis (Motshekga, 2011). The educational crisis is particularly disconcerting given the mammoth challenges of dealing with the legacies of substandard and unequal education practices left by apartheid (Lumadi, 2008). Quality education entails the enrichment of cognitive skills and the younger generation must be trained, through their schooling, to positively contribute to society in the future (Lolwana, 2007). The role of the South African Department of Education in addressing these challenges is brought into sharp focus under the auspices of transformational strategies and policies of improving the delivery of quality education to all learners (Department of Basic Education, 2012; Hammett, 2008; Lolwana, 2007; Rademeyer, 2013).

Envisaged transformation towards quality education depends primarily on teachers being in the classrooms, every day, doing what they are supposed to be doing - teaching the learners (Jansen, 2007). To ensure that this is taking place, the underlying individual attitudes, beliefs and social structures that unconsciously drive the observable behaviours must be examined, understood and explained in order for them to be changed. True transformation necessitates changing the underlying motivation or attitude, not merely rearranging the existing observable behaviour (Berliner, 2002). Consequently, improving the work attitude of teachers is now being aimed at (Department of Basic Education, 2012).

\section{Experience of a sense of calling}

In the opinion of Wrzesniewski, McCauley, Rozin and Schwartz (1997), a sense of calling relates to a person's motivation to perform their duties, especially in social occupations such as teaching. However, researchers report incongruent definitions of what does or does not constitute a sense of calling (Hirschi, 2011). Historically, the origin of a sense of calling lies within the religious framework where the individual is said to receive a 'transcendent summons, experienced as 
originating beyond the self, to approach a particular life role' (in this case work) (Dik \& Duffy, 2009, p. 427; Elangovan, Pinder \& McLean, 2010). As research on this concept continued, the definition was altered to include any 'honest' line of work as long as the individual was still motivated to serve the greater purpose and common good (Hunter, Dik \& Banning, 2010). This change in the definition was motivated from psychologists' notion to regard religious discussions with clients as inappropriate and therefore a sense of calling had to be conceptualised as a more modern and secular idea (Bergin \& Jensen, 1990).

The modern definition of calling includes a sense of purpose, direction, the desire to be helpful and personal fulfilment (Dik, Duffy \& Eldridge, 2009; Elangovan et al., 2010; Hall \& Chandler, 2005; Steger, Pickering, Shin \& Dik, 2010; Wrzesniewski et al., 1997), which became known as the secular view of a sense of calling and it recognises people's desire to contribute to the greater good (Dik \& Duffy, 2009; Steger \& Dik, 2010). Personal fulfilment and serving the greater good are viewed as important factors of a person's work experience, regardless of the individual's religious views (Hall \& Chandler, 2005).

For the purpose of this study sense of calling will be conceptualised as search and presence of calling (Duffy \& Sedlacek, 2007). The teachers who report a presence of a calling have a good sense of their interests and abilities, they are more likely to be mature in their career development process and they are more comfortable in making career decisions. Conversely, teachers that report a search for calling tend to be slightly more indecisive and slightly more likely to lack a clear career development process; these individuals are less comfortable in making career decisions and are markedly less clear about their interests and abilities (Duffy \& Sedlacek, 2007). However, Dik, Eldridge, Steger and Duffy (2012) suggest that a sense of calling must be comprehended to be a process in which the individual experiences, maintains and seeks their callings on a continuous basis.

Research studies explore and propose some benefits to experiencing one's work as a calling, which include high levels of life satisfaction, zest and an overall feeling of contributing to the greater good and low levels of absenteeism (Wrzesniewski et al., 1997). It is therefore argued that work becomes socially valuable to the individual who experiences work as a calling: work becomes an end in itself, inseparable from the person's life (Duffy, Dik \& Steger, 2011; Treadgold, 1999; Wrzesniewski et al., 1997). Renewed interest in the once valued notion of experiencing work as a calling was caused by people testifying to having a more positive work attitude when work is approached as a calling (Duffy et al., 2011; Elangovan et al., 2010; Hall \& Chandler, 2005; Steger et al., 2010).

\section{Work attitude}

An attitude is a tendency of an individual to react to a certain object, be it a person, idea or situation (Chambers \& Forlin,
2010; Nel et al., 2011). This reaction can either be positive or negative and is based upon previous, personal experiences (TIP: Concepts, 2010). Therefore an attitude can change as the experience of the individual changes ( $\mathrm{Nel}$ et al., 2011) or it can be adjusted as implicit learning takes place (Zimbardo \& Leippe, 1991).

South African teachers are more than ever displaying a negative attitude towards the teaching profession (Eloff \& Kgwete, 2007) as is evident in their own and publicly expressed opinions that they are ill prepared to meet the needs of the diverse learners in the classrooms (Lumadi, 2008). Teachers are also overwhelmed with and by constant changes in the education system, placing additional demands on the already negative teachers. They had to adapt to the outcomes-based curriculum and, shortly afterwards, the newly announced national Curriculum and Assessment Policy Statement (CAPS) (Department of Basic Education, 2012; Talmor, Reiter \& Feigin, 2005). Due to the government's transformation strategy, teachers find themselves inundated by an excessive workload which includes classroom activities, extramural activities as well as administrative functions, all of which is exacerbated by teachers' lack in capacity to work with, understand and interpret the curriculum (Lolwana, 2007).

The importance of the teachers' work attitude is reiterated in order to ensure successful transformation and the delivery of quality education to learners as teachers still remain the curriculum agents in the classroom (Carl, 2002; Department of Basic Education and Higher Education and Training, 2011; Jerlinder, Danermark \& Gill, 2010; Kuyini \& Desai, 2007; Nel et al., 2011). Teachers' work attitude will either foster optimal teaching and learning or hinder growth of learners (Carl, 2002) as the teachers' intentions and behaviour in the classroom are directly influenced by their work attitude (Chambers \& Forlin, 2010; Nel et al., 2011).

Recent studies propose that work attitude not simply relates to, but also significantly predicts, work satisfaction (Dik \& Duffy, 2009; Dik et al., 2009; Steger \& Dik, 2010). Hall and Chandler (2005) further argue that the personal experience of work satisfaction and meaningful work influences people's work attitude. As a result of this interaction between work satisfaction and work attitude, contemporary researchers are of the opinion that if teachers experience meaningful work, theirattitudetowardsteaching willbemorepositive(European Agency for Development in Special Needs Education, 2010; Hall \& Chandler, 2005). Therefore, a positive teacher work attitude may be beneficial for positively impacting the teacher's ability to create a classroom atmosphere that will be conducive to quality education (Andrews, 2002; Cook, 2002; Meijer, Soriano \& Watkins, 2006; Pearson, 2007; Reinke \& Moseley, 2002; Silverman, 2007).

It can be argued that quality education can only be achieved once positive, high-performance, quality teachers are employed. McKinsey and Company (2007) also points out in his report that one must get 'the right people to become teachers to ensure excellent instruction' (p. 37) thereby 
ensuring quality education and transformation. The inability to adequately address a negative teacher attitude seriously hampers progress towards quality education (Atkinson, 2004; Forlin, Loreman, Sharma \& Earle, 2009).

This study conceptualises work attitude in terms of (1) work challenge and work enjoyment (Amabile, Hill, Hennessey \& Tighe, 1994), which is an indication of the individual's selfperception and motivation for choice of work, and (2) career decidedness (Jones, 1989), which indicates the degree to which the individual feels certain about their career choice.

Research focusing on teachers and their work attitudeindicates that teachers are more positive towards their profession if (1) they feel supported by management and parents in facing daily challenges, (2) the school atmosphere and learner behaviour are pleasant and (3) a career development process is in place that will result in desirable career outcomes such as job security, satisfaction and commitment (Müller, Alliata \& Benninghoff, 2009). It is also believed by researchers that a positive work attitude will increase the delivery of quality education. In addition, if teachers perceive that what they are doing is meaningful, they will consistently try to change for the better (positively).

\section{Meaningful work}

Meaningful work is viewed as a major part of life (Dik \& Duffy, 2009; Rosso, Dekas \& Wrzesniewski, 2010) and is experienced as both significant and positive (meaningfulness) and has a eudemonic (growth and purpose oriented) focus (Rosso et al., 2010). For purposes of this study, meaningful work is conceptualised as consisting of (1) positive meaning in work, which captures the sense that people judge their work to matter and be meaningful, (2) meaning-making through work, which is inclusive of self-directed actions in seeking meaningful work and facilitating personal growth, and (3) greater good motivations, which entails the desire to make a positive impact on the greater good (Dik \& Duffy, 2009; Rosso et al., 2010).

In line with the view that people wish to experience meaningful work, Isaksen (2000) adds that meaningful work results in less boredom and a less negative work attitude and that finding meaningful work is as important to the individual as job security and a salary (O'Brien, 1992). This highlights the importance of understanding meaningful work because people's work attitude depends on the meaning they derive from their work (Steger, Dik \& Duffy, 2012; Wrzesniewski et al., 1997).

\section{Purpose of the study}

Wrzesniewski et al. (1997) are of opinion that teachers are more likely to experience their work as a sense of calling. However, little research has been done worldwide, and especially in the South African context, to investigate this perception. Furthermore, worldwide transformation and change in education is placing increased demands on teachers, which

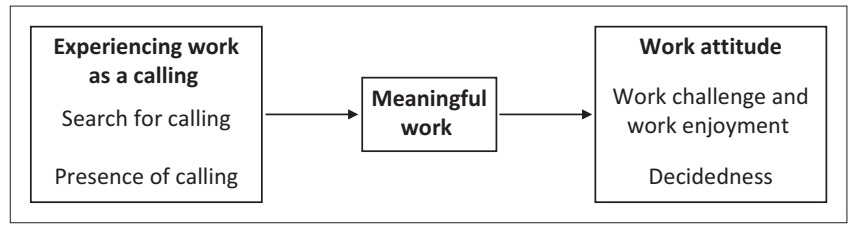

Source: Steger, M.F., Pickering, N.K., Shin, J.Y., \& Dik, B.J. (2010). Calling in work: Secular or sacred? Journal of Career Assessment, 18(1), 82-96. http://dx.doi.org/10.1177/ or sacred? Journal
1069072709350905

FIGURE 1: The hypothesised relationship between meaningful work as a mediator of the relationship between experiencing work as a sense of calling and work attitude.

could potentially have a negative impact on their work attitude. As noted, this includes reducing their experience of work as a challenge and reducing their work enjoyment and career decisiveness. Moreover, little research has explored the interrelationship amongst experiencing work as a sense of calling, work attitude and meaningful work. Accordingly, the purpose of this study is to explore the interrelationship amongst these constructs in South African teachers by testing meaningful work as a mediator of the relationship between a sense of calling and work attitude (see Figure 1).

As illustrated in Figure 1, teachers' experience of a sense of calling has an indirect effect on work attitude through meaningful work. The empirical model of Steger et al. (2010) was adapted and applied in this study to investigate teachers' work attitude. For the purpose of this study, the mediation or indirect effect hypothesis posits how, or by what means, the independent variable (experiencing a sense of calling) affects the dependent variable (work attitude) through the potential intervening or mediating variable or mediator (meaningful work). This is a simple mediation model that explores how the causal effect that experiencing a sense of calling has on work attitude can be apportioned into the indirect effect that a sense of calling has on work attitude through meaningful work, and the direct effect that a sense of calling has on work attitude.

Based on the discussion above, the following research questions were formulated:

1. What is the relationship between the teacher's experience of a sense of calling and their work attitude?

2. Does experiencing a sense of calling have an indirect effect on work attitude through meaningful work?

Hence, it was hypothesised that (1) there is a significant positive relationship between experiencing a sense of calling and a positive work attitude amongst teachers and (2) the relationship between experiencing a sense of calling and work attitude amongst teachers is mediated by meaningful work, that is, sense of calling has an indirect effect on work attitude through meaningful work.

\section{Research design Research approach}

The authors used a quantitative research approach to achieve the research objectives. More specifically, they 
TABLE 1: Characteristics of the participants $(n=270)$.

\begin{tabular}{|c|c|c|c|}
\hline Item & Category & $f$ & $\%$ \\
\hline \multirow[t]{6}{*}{ Age } & 24 years and younger & 19 & 7.2 \\
\hline & $25-35$ years & 62 & 23.6 \\
\hline & $36-45$ years & 58 & 22.2 \\
\hline & $46-55$ years & 90 & 34.5 \\
\hline & 56 years and older & 29 & 11.0 \\
\hline & Missing values & 4 & 1.5 \\
\hline \multirow[t]{3}{*}{ Gender } & Female & 203 & 77.5 \\
\hline & Male & 58 & 22.1 \\
\hline & Missing values & 1 & 0.4 \\
\hline \multirow[t]{9}{*}{ Ethnicity } & English & 12 & 4.6 \\
\hline & Afrikaans & 185 & 70.6 \\
\hline & Sotho & 49 & 18.7 \\
\hline & Xhosa & 5 & 1.9 \\
\hline & Zulu & 6 & 2.2 \\
\hline & Tswana & 1 & 0.4 \\
\hline & Indian & 2 & 0.8 \\
\hline & Other & 0 & 0.0 \\
\hline & Missing values & 2 & 0.8 \\
\hline \multirow[t]{5}{*}{ Experience } & $<5$ years & 45 & 17.2 \\
\hline & $5-9$ years & 52 & 19.8 \\
\hline & $10-14$ years & 20 & 7.6 \\
\hline & $>15$ years & 144 & 55.0 \\
\hline & Missing values & 1 & 0.4 \\
\hline
\end{tabular}

f, frequency.

used a non-probability sample in the form of a purposive, convenience sample to collect data on the experience of a sense of calling, work attitude and the influence of meaningful work on teachers at a particular point in time.

\section{Research method}

\section{Research participants}

A convenience sample of teachers in secondary education institutions $(N=270)$ participated in this study. The institutions were all part of the Fezile Dabi school district which is located in the north-western corner of the Free State province of South Africa. The schools included rural and township schools as well as schools in more affluent areas of the district. A total of 500 questionnaires were distributed, of which 270 were returned (response rate $=54 \%$ ).

Table 1 displays the characteristics of this representative sample of the population. The majority of the participants were between 46 and 55 years of age (34.5\%), followed by the 25-35-year age group (23.6\%). Women comprised 77.5\% of the sample and men $22.1 \%$. Afrikaans-speaking people dominated the sample (70.6\%), followed by Sotho speakers $(18.7 \%)$ and English speakers (4.6\%). The distribution of participants by experience was: fewer than 5 years (17.2\%), 5 to 9 years $(19.8 \%), 10-14$ years $(7.6 \%)$ and 15 years and more $(55 \%)$.

\section{Measuring instruments}

Sense of calling: The authors measured sense of calling by using the Calling and Vocation Questionnaire (CVQ), developed by Dik et al. (2012). This multidimensional, 24-item scale measures (1) the presence of a calling (individuals who perceive that they currently experience a sense of calling) as well as (2) the search for a sense of calling (individuals who may not currently experience a sense of calling but who are actively seeking one). A Likert-type scale ranging from 1 (not at all true of me) to 4 (totally true of me) was used. Reliability of this measure was reported as Cronbach's alpha coefficients of 0.90 for CVQ Presence and 0.91 for CVQ Search (Dik et al., 2012).

Work attitude: This construct was divided into two subsections measured by means of different questionnaires. The first subsection measures work challenge and work enjoyment: the Work Preference Inventory (WPI) developed by Amabile et al. (1994), which consists of 30 items, divided into two sub-scales. A Likert-type scale ranging from 1 (never or almost never true of me) to 4 (always or almost always true of me) was used. Amabile et al. reported a Cronbach's alpha coefficient of 0.70 (work enjoyment $=0.67$; work challenge $=0.73$ ).

The second subsection of work attitude, decidedness, was measured by means of the Career Decision Profile (CDP) (Jones, 1989). This is a 16-item scale that is used to determine whether the individual thinks decisively about their career choice. A Likert-type scale ranging from 1 (strongly disagree) to 8 (strongly agree) was used. In the study done by Jones (1989), the CDP scored a reliable Cronbach's alpha coefficient of 0.84 .

Meaningful work: Assessing meaningful work was done by administering the Work and Meaning Inventory (WAMI) developed by Steger et al. (2012). This 10-item scale measures the individual's search for and experience of meaning and purpose in life. A Likert-type scale ranging from 1 (absolutely untrue) to 5 (absolutely true) was used. The study done by Steger et al. reported a Cronbach's alpha coefficient of 0.86 .

\section{Research procedure and ethical considerations}

This research project was evaluated and accepted by the Ethics Committee of the North-West University (Vaal Triangle Campus), South Africa. The researcher approached and explained the research project to the Department of Education in order to gain permission to conduct the research study. The school principals were met with individually prior to the research in order to explain the process and to obtain permission as to when the questionnaires could be distributed and collected in their schools.

The participants were fully informed regarding the research process. The researcher allowed participants to ask questions and raise concerns about the project before considering participation. The researcher outlined the roles and responsibilities of all the parties involved. Participation was anonymous, voluntary and informed consent was obtained. This informed consent form stated that the researcher would use the information obtained from the study for research purposes only. Feedback on the results of the study was restricted to the school principals. 
The researcher administered a self-reporting questionnaire to those who presented themselves and agreed to participate in the study. A covering letter accompanied the questionnaire, which explained the purpose and emphasised the confidentiality of the research project. After data gathering, raw data were captured and datasheets were converted to an SPSS dataset.

\section{Statistical analysis}

The authors used SPSS and Mplus version 6.12 to analyse the data. Descriptive statistics (means, standard deviations, skewness and kurtosis) and inferential statistics (correlations) were employed. Confirmatory data analysis (CFA) was used to test the factorial validity of the measuring instruments. Cronbach's alpha and Raykov's rho coefficients were used to assess the reliability of the scales. Pearson product-moment correlation coefficients were used to measure the proposed relationships between the variables. Practical significance of the results was determined by using effect sizes (Cohen, 1988).

The following indices produced by Mplus were used in this study: the chi-square statistic (the test of absolute fit of the model) and root means square error of approximation (RMSEA). A robust weighted least squares estimator (WLSMV) was employed as the data were defined as categorical and acceptable fit of models cannot be compared based on the chi-square values only. Incremental fit indices, including the Tucker-Lewis index (TLI) and the comparative fit index (CFI), were also considered. The authors agreed that TLI and CFI values higher than 0.90 are considered acceptable. RMSEA values lower than 0.08 indicate an acceptable fit between the model and the data (Hu \& Bentler, 1999). The Akaike information criterion (AIC) and Bayes information criterion (BIC) were not used as these criteria are not effectively developed to calculate second order variables as part of model measurements.

The bootstrapping method was used in this study in order to test mediation. The method was set at 5000 draws (Hayes, 2009). The confidence interval was set at $95 \%$. When zero is not in the $95 \%$ confidence level, one can conclude that the indirect effect is significant at $p$ less than 0.05 .

\section{Results}

\section{Testing the measurement model}

The authors used CFA to assess whether each of the measurement items would load significantly onto the scales with which they were associated and problematic items were removed to improve the construct validity of the measurement instrument used in the study. The authors tested three measurement models. Model 1 consisted of two first order latent variables: sense of calling (18 items, inclusive of both search for and presence of calling) and meaningful work (nine items), as well as one second order latent variable, consisting of three first order latent variables, namely work challenge (eight items), work enjoyment (four
TABLE 2: Fit statistics for the competing measurement models.

\begin{tabular}{lccccc}
\hline Model & $\chi^{2}$ & $d f$ & RMSEA & CFI & TLI \\
\hline Model 1 & 2687.82 & 813 & 0.09 & 0.84 & 0.83 \\
Model 2 & 1721.82 & 811 & 0.06 & 0.92 & 0.92 \\
Model 3 & 1644.32 & 810 & 0.06 & 0.93 & 0.93 \\
\hline
\end{tabular}

$\chi^{2}$, chi-square; $d f$, degrees of freedom; RMSEA, root mean square error of approximation CFI, comparative fit index; TLI, Tucker-Lewis index

TABLE 3: Difference testing for competing measurement models.

\begin{tabular}{lccc}
\hline Model & $\Delta \chi^{2}$ & $\Delta d f$ & $p$-value \\
\hline Model 1 & 278.59 & 3 & $<0.0001^{* *}$ \\
Model 2 & 36.86 & 1 & $<0.0001^{* *}$ \\
\hline$\chi^{2}$, chi-square; $d f$, degrees of freedom & & \\
$*, p<0.05$. & & \\
$* *, p<0.01$. & &
\end{tabular}

items) and decidedness (three items). Model 2 consisted of three first order latent variables, search for calling (five items), presence of calling (13 items), meaningful work (nine items), as well as one second order latent variable consisting of two first order latent variables, namely work challenge and enjoyment combined (12 items) and decidedness (three items).

Model 3 consisted of three first order latent variables, search for calling (five items), presence of calling (13 items) and meaningful work (nine items), as well as one second order latent variables consisting of three first order latent variables namely work challenge (eight items), work enjoyment (four items) and decidedness (three items). Table 2 presents fit statistics for the test of various measurement models.

Comparison of the fit indices indicates that model 3 fitted the data best with the following indicators: $\chi^{2}$ value of 1644.32 $(d f=810)$, RMSEA of 0.06, CFI of 0.93 and TLI of 0.93 . The hypothesised model had an acceptable fit with the data on the fit indices. However, chi-square values cannot be directly compared (Satorra \& Bentler, 2010); subsequently, chi-square difference testing had to be performed to determine how the chi-square would change between the different models.

Table 3 reports the difference testing for competing measurement models. The results indicated that both model 1 and model 2 had significant $p$-values, which suggests a significantly worse fit than model 3 . Therefore, model 3 was the best fitting model.

\section{Testing the structural model}

The descriptive statistics and Raykov's rho coefficients of the measuring instruments, as well as the product-moment correlation coefficients between the constructs, are reported in Table 4.

As per the results in Table 4, it is evident that the scales used in the research are reliable with values greater than 0.7 (Nunnally \& Bernstein, 1994; Wang \& Wang, 2012). Results for Cronbach's alpha coefficients ranged from 0.84 to 0.91 , whilst Raykov's rho coefficients ranged from 0.81 to 0.95 . Both measures of reliability were included as it was not possible to calculate Cronbach's alpha coefficients for work attitude. 
TABLE 4: Descriptive statistics, Raykov's rho and correlation coefficients of the scales.

\begin{tabular}{|c|c|c|c|c|c|c|c|c|c|c|}
\hline Scale & $\mathbf{M}$ & SD & Skewness & Kurtosis & $\alpha$ & $P$ & 1 & 2 & 3 & 4 \\
\hline 1. Search for calling & 2.67 & 0.79 & -0.21 & -0.72 & 0.84 & 0.91 & - & - & - & - \\
\hline 2. Presence of calling & 3.16 & 0.53 & -0.46 & -0.08 & 0.89 & 0.93 & $0.43 * *_{+}$ & - & - & - \\
\hline 3. Meaningful work & 3.19 & 0.57 & -0.53 & 0.26 & 0.91 & 0.95 & $0.23 * *$ & $0.88 * *++$ & - & - \\
\hline 4. Work attitude & 3.13 & 0.53 & -0.62 & 0.48 & - & 0.81 & $0.31 * *+$ & $0.65 * *++$ & $0.69 * *++$ & - \\
\hline
\end{tabular}

$\mathrm{M}$, mean; SD, standard deviation; $\alpha$, alpha.

**, Correlation is significant at the 0.01 leve

+ , Correlation is practically significant $r>0.30$ (medium effect).

++ , Correlation is practically significant $r>0.50$ (large effect).

TABLE 5: Initial framework fit indices and standardised path coefficients.

\begin{tabular}{lccc}
\hline Measures & $\begin{array}{c}\text { Indirect effects } \\
\text { (Model 1) }\end{array}$ & $\begin{array}{c}\text { Direct effects } \\
\text { (Model 2) }\end{array}$ & $\begin{array}{c}\text { Direct and indirect } \\
\text { effects (Model 3) }\end{array}$ \\
\hline Fit indices & 1644.90 & 7580.91 & 1644.32 \\
$\chi^{2}$ & 812 & 812 & 810 \\
$d f$ & 0.93 & 0.43 & 0.93 \\
$\mathrm{CFI}$ & 0.93 & 0.39 & 0.93 \\
TLI & 0.06 & 0.18 & 0.06 \\
RMSEA & - & & \\
Direct effects on work attitude & $0.64^{* *}$ & 0.05 \\
Presence of calling & - & 0.03 & 0.14 \\
Search for calling & $0.72 * *$ & $0.69 * *$ & $0.62^{* *}$ \\
Meaningful work & & & \\
Direct effects on meaningful work & - & $0.96 * *$ \\
Presence of calling & $0.94^{* *}$ & - & $-0.18^{* *}$ \\
\hline
\end{tabular}

$\chi^{2}$, chi-square; $d f$, degrees of freedom; RMSEA, root mean square error of approximation; $\mathrm{CFI}$ comparative fit index; TLI, Tucker-Lewis index.

$* *, p<0.01$

Furthermore, Table 4 provides the correlation coefficients of the variables. All the variables were statistically significant $(p<0.01)$ and positively related to each other. Search for calling correlated practically significantly with presence of calling and work attitude (medium effect). Presence of calling correlated practically significantly with meaningful work and work attitude (large effect). Lastly, meaningful work correlated practically significantly with work attitude (large effect).

The authors hypothesised that there is a significant positive relationship between experiencing a sense of calling and work attitude amongst teachers (hypothesis 1). Based on the correlations reported it is evident that both search for calling $(r=0.31 * *+)$ and presence of calling $\left(r=0.65^{* *++}\right)$ are significantly positive related to work attitude. Therefore, hypothesis 1 can be accepted.

Measurement model 3 formed the basis of the structural model that was tested by the authors. The hypothesised relationships shown in the model were tested, using latent variable modelling as implemented by Mplus. Table 5 presents fit statistics for testing competing models.

The authors tested the hypothesised relationships using latent variables modelling as Mplus implements it. In model 1 (indirect effects), they included paths from search for calling to meaningful work and work attitude, paths from presence of calling to meaningful work and work attitude, and lastly paths from meaningful work to work attitude. The authors obtained a $\chi^{2}$ value of $1644.90(d f=812)$ for the hypothesised model. The fit statistics on the indices were acceptable: CFI 0.93, TLI 0.93
TABLE 6: Difference testing for competing structural models.

\begin{tabular}{lccc}
\hline Model & $\Delta \chi^{2}$ & $\Delta d f$ & $p$-value \\
\hline Model 1 & 567.30 & 2 & $<0.0001^{* *}$ \\
Model 2 & 8.52 & 2 & $0.01^{*}$ \\
\hline
\end{tabular}

$\chi^{2}$, chi-square; $d f$, degrees of freedom.

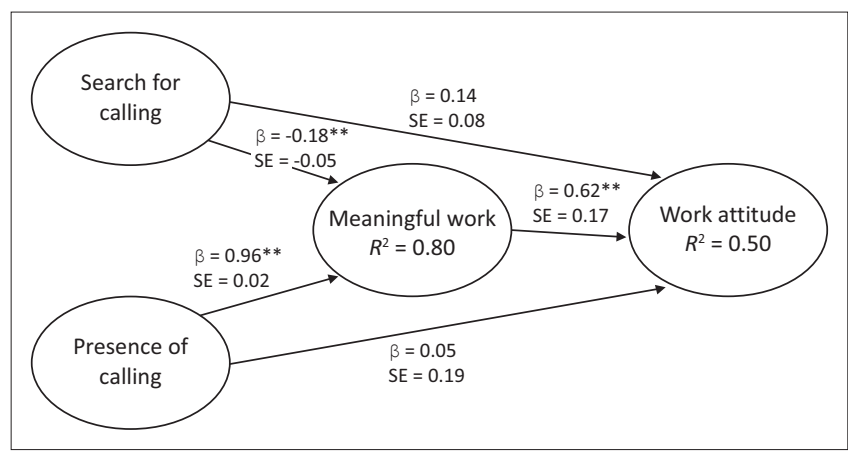

FIGURE 2: Standardised path coefficients for model 3.

and RMSEA 0.06. Model 2 (direct effects) included paths from presence of calling, search for calling and meaningful work to work attitude, respectively, and yielded the following fit statistics: a $\chi^{2}$ value of $7580.91(d f=812)$, CFI of 0.43 , TLI of 0.39 and RMSEA of 0.18 . Model 3 (direct and indirect effects), with paths from presence of calling and search for calling to meaningful work, as well as from meaningful work to work attitude, showed the following fit statistics: a $\chi^{2}$ value of $1644.32(d f=810)$, CFI of 0.93 , TLI of 0.93 and RMSEA of 0.06 . As structural model 1 and model 3 appear to indicate similar fit indices, difference testing between structural models was performed as reported in Table 6.

The results indicated that both model 1 and model 2 had significant $p$-values, which suggests a significantly worse fit than model 3 . Therefore, model 3 was the best fitted model.

Figure 2 shows the standardised path coefficients estimated by Mplus for structural model 3.

The path coefficient of a search for calling predicting work attitude $(\beta=0.14)$ and a presence of calling predicting work attitude $(\beta=0.05)$ were not significant but had the expected sign. The path coefficient for meaningful work predicting work attitude was significant and positive $(\beta=0.62, p<0.01)$. For the portion of the model that predicts meaningful work, the path coefficient of search for calling was significant and negative $(\beta=-0.18, p<0.01)$ and presence of calling was significant and positive $(\beta=0.96, p<0.01)$. 
TABLE 7: Indirect effects of sense of calling.

\begin{tabular}{lccccc}
\hline & \multicolumn{5}{c}{ Work attitude } \\
\cline { 2 - 6 } Variable & Est & SE & z-value & $\begin{array}{c}\text { BC 95\% Cl } \\
\text { Lower }\end{array}$ & $\begin{array}{c}\text { BC 95\% Cl } \\
\text { Upper }\end{array}$ \\
\hline Search for calling & $-0.11^{*}$ & 0.06 & -1.97 & -0.22 & -0.01 \\
Presence of calling & $0.59 * *$ & 0.22 & 2.65 & 0.15 & 1.02 \\
\hline Est, estimate; SE, standard error. & & & & \\
$*, p<0.05$. & & & & \\
$* *, p<0.01$.
\end{tabular}

\section{Testing the indirect effect}

To determine whether the relationship between the experience of a sense of calling and work attitude was mediated by meaningful work, the authors used the procedure explained by Hayes (2009). Bootstrapping was used to construct twosided bias-corrected 95\% confidence intervals (CIs) so as to evaluate the indirect effect of calling on work attitude through meaningful work. Lower and upper CIs are reported in Table 7.

With regard to meaningful work and a mediator of the relationship between a sense of calling and work attitude, the $95 \%$ CIs did not include zero $(p<0.05)$. Therefore, a sense of calling does have an indirect effect on work attitude through the mediating variable, meaningful work. Hypothesis 2 stated that meaningful work is a mediator of the relationship between experiencing a sense of calling and work attitude amongst teachers. The results found that a sense of calling has a significant indirect effect on work attitude, thereby supporting hypothesis 2 that meaningful work serves as a mediating variable between a sense of calling and work attitude. Furthermore, the significant positive indirect effect of presence of calling on work attitude suggests that as perceptions of meaningful work increase, increase in presence of calling are needed to impact work attitude. In contrast, the significant negative indirect effect of search for calling on work attitude suggests that as perceptions of meaningful work decrease, increases in search for calling are needed to impact work attitude.

\section{Discussion}

The objective of this study was to investigate the relationship between experiencing a sense of calling and work attitude of teachers in South Africa, and also to investigate if meaningful work served as a mediator in the relationship between a sense of calling and work attitude.

The results indicated that two distinct types of calling experiences could be identified, namely search for calling and presence of calling. The existence of these types are consistent with previous research, which established that having a sense of calling in one's career can be a static orientation, presence of calling (Duffy \& Sedlacek, 2007; Wrzesniewski et al., 1997), or it can be a process in which the teacher constantly experiences, maintains and seeks a calling, thus search for calling (Dik et al., 2012).

The results further indicated that there is a statistically and practically significant relationship between experiencing a sense of calling and work attitude amongst teachers. This opens up the influential question of whether the wellresearched and documented positive effects of experiencing a sense of calling are manifested by teachers in South Africa (Dik et al., 2009; Elangovan et al., 2010; Hall \& Chandler, 2005; Müller et al., 2009; Steger et al., 2010). If these effects were at all true of the South African teachers, the reported absenteeism levels would have been much lower compared to other vocations (Wrzesniewski et al., 1997) and positive work attitude would have been evident in classrooms at all times (Duffy et al., 2011; Elangovan et al., 2010; Hall \& Chandler, 2005; Steger et al., 2010). In South Africa, the opposite behaviour is manifest: absenteeism levels are high and teachers find it difficult to display a positive work attitude in classrooms.

Furthermore, the results indicated that meaningful work serves as a mediator of the relationship between experiencing a sense of calling and work attitude amongst South African teachers. This implies that work attitude of teachers is indirectly influenced by experiencing a sense of calling (both search of and presence of) through meaningful work. This search for and presence of calling does not directly influence work attitude, but when a teacher experiences meaningful work, having a sense of calling could increase work attitude. The relationships between search for calling and presence of calling and meaningful work needs to be clarified. The negative beta between search for calling and meaningful work suggests that as meaningful work increases, decreases in search for calling are needed to impact work attitude. In contrast, the positive beta between presence of calling and meaningful work suggests that as meaningful work increases, increases in presence of calling is needed to impact work attitude. Meaning in work can therefore be seen as a mechanism of action for how experiencing a sense of calling impacts work attitude.

The study specifically points out that meaningful work entails the understanding of work as being significant, serving the greater good and with the objective of personal growth (Dobrow, 2004; Rosso et al., 2010; Steger et al., 2012). In practice, this leads to teachers objectively judging their work as meaningful and impacting on the greater good of humankind. Teachers who experience increased levels of work attitude will be able to change their behaviour in classrooms (Berliner, 2002), resulting in learners changing their behaviour too, aiding in the creation of a conducive learning environment. This could empower teachers to deliver quality education to all learners and be the change agents towards educational transformation (Department of Basic Education and Higher Education and Training, 2011; Jerlinder et al., 2010; Nel et al., 2011). Teachers who successfully gain self-perception as to who they are, their motivations towards work challenges and their choice of career are more likely to display a positive work attitude (Dik et al., 2012; Elangovan et al., 2010; Hall \& Chandler, 2005; Müller et al., 2009; Steger et al., 2010; Wrzesniewski et al., 1997). 
Limitations of the present study include that data were retrieved from a cross-sectional research design that utilised a structured questionnaire. Hence, no causal inferences could be made. The results of this study are very sample dependent in terms of the actual nature of the data and do not reflect pre-imposed patterns; hence the importance to replicate this study with other, larger samples to support generalisability of the results. The study was conducted amongst teachers; thus the results obtained from this study may only be used in the educational context. Moreover, the questionnaires were only available in English and this may have affected the results, as some respondents' first language may not be English. This may result in respondents not fully comprehending the questions; translation of the questionnaires could have helped in obtaining more reliable results.

Through this study distinctive insights were provided into the relationship between experiencing a calling, work attitude and meaningful work. However, more in-depth, longitudinal and qualitative research is needed to fully comprehend the interaction amongst these constructs. To increase the likelihood of teachers actively engaging in the delivery of quality education, interventions should be developed based on empirical results. Therefore, the measures used in future research could be refined even more.

\section{Acknowledgements}

This work is done under the auspice of the Optentia Research Programme, North-West University (Vaal Triangle Campus), South Africa. This work also uses the research that the Free State Department of Education supported as its basis. Any opinion, finding, conclusion or recommendation in this article is that of the authors.

\section{Competing interests}

The authors declare that they have no financial or personal relationships that may have inappropriately influenced them in writing this article.

\section{Authors' contributions}

E.D. (North-West University) was the study leader in this project. M.W. (North-West University) conducted the literature review and facilitated the completion of the questionnaires. Both authors were involved in the analysis of the data and writing up the manuscript.

\section{References}

Amabile, T.M., Hill, K.G., Hennessey, B.A., \& Tighe, E.M. (1994). The work preference inventory: Assessing intrinsic and extrinsic motivational orientations. Journal of Personality and Social Psychology, 66, 950-967. http://dx.doi.org/10.1037/0022 3514.66.5.950, PMID: 8014837.

Andrews, L. (2002). Preparing general education pre-service teachers for inclusion: Web-enhanced case-based instruction. Journal of Special Education Technology, 17, 27-35.

Atkinson, D. (2004). Theorising how student teachers form their identities in initial teacher education. British Educational Research Journal, 30(3), 379-394. http:// dx.doi.org/10.1080/01411920410001689698
Bergin, A.E., \& Jensen, J.P. (1990). Religiosity of psychotherapists: A national survey Psychotherapy: Theory, Research, Practice, Training, 27, 3-7. http://dx.doi. org/10.1037/0033-3204.27.1.3

Berliner, D.C. (2002). Comment: Educational research: The hardest of all. Educational Researcher, 31(3), 18-20. http://dx.doi. org/10.3102/0013189X031008018

Carl, A.E. (2002). Teacher empowerment through curriculum development. (2nd edn.). Landsdowne, South Africa: Juta \& Company.

Chambers, D., \& Forlin, C. (2010). Initial teacher education and inclusion: A triad of inclusive experiences. In C. Forlin (Ed.), Teacher education for inclusion: Changing paradigms and innovative approaches (pp. 74-83). Abingdon, VA: Routledge.

Cohen, J. (1988). Statistical power analysis for the behavioral sciences. Orlando, FL: Academic Press.

Cook, B.G. (2002). Inclusive attitudes, strengths, and weaknesses of pre-service general educators enrolled in a curriculum infusion teacher preparation program. Teacher Education and Special Education, 25, 262-277. http://dx.doi. org/10.1177/088840640202500306

Department of Basic Education. (2012). Action plan to 2014: Towards the realisation of schooling 2025. Pretoria, South Africa: Government Printer.

Department of Basic Education and Higher Education and Training. (2011). Integrated strategic planning framework for teacher education and development in South Africa: 2011-2025. Pretoria, South Africa: Government Printer.

Dik, B.J., \& Duffy, R.D. (2009). Calling and vocation at work: Definitions and prospects for research and practice. The Counseling Psychologist, 37, 424-450. http:// dx.doi.org/10.1177/0011000008316430

Dik, B.J., Duffy, R.D., \& Eldridge, B.M. (2009). Calling and vocation in career counseling: Recommendations for promoting meaningful work. Professional Psychology: Research and Practice, 40, 625-632. http://dx.doi.org/10.1037/a0015547

Dik, B.J., Eldridge, B.M., Steger, M.F., \& Duffy, R.D. (2012). Development and validation of the Calling and Vocation Questionnaire (CVQ) and Brief Calling Scale (BCS). Journal of Career Assessment, 20(3), 242-263. http://dx.doi. org/10.1177/1069072711434410

Dobrow, S. (2004). Extreme subjective career success: A new integrated view of having a sense of calling. In Best paper proceedings of the academy of management conference held at Harvard Business School. Boston, MA: Academy of Management.

Duffy, R.D., Dik, B.J., \& Steger, M.F. (2011). Calling and work-related out-comes: Caree commitment as a mediator. Journal of Vocational Behavior, 78, 210-218. http:// dx.doi.org/10.1016/j.jvb.2010.09.013

Duffy, R.D., \& Sedlacek, W.E. (2007). The presence of and search for a calling: Connections to career development. Journal of Vocational Behavior, 70, 590-601. http://dx.doi.org/10.1016/j.jvb.2007.03.007

Elangovan, A.R., Pinder, C.C., \& McLean, M. (2010). Callings and organizational behaviour. Journal of Vocational Behavior, 76, 428-440. http://dx.doi. org/10.1016/j.jvb.2009.10.009

Eloff, I., \& Kgwete, L.K. (2007). South African teachers' voices on support in inclusive education. Retrieved September 10, 2011, from http://www.thefreelibrary.com// print/printarticle. aspx?id=168163366

European Agency for Development in Special Needs Education. (2010). Teacher education for inclusion - International literature review. Odense, Denmark: European Agency for Development in Special Needs Education.

Forlin, C., Loreman, T., Sharma, U., \& Earle, C. (2009). Demographic differences in changing pre-service teachers' attitudes, sentiments and concerns about inclusive education. International Journal of Inclusive Education, 13(2), 195-209. http:// dx.doi.org/10.1080/13603110701365356

Hall, D.T., \& Chandler, D.E. (2005). Psychological success: When the career is a calling. Journal of Organizational Behavior, 26, 155-176. http://dx.doi.org/10.1002/ job.301

Hammett, D. (2008). Disrespecting teacher: The decline in social standing of teachers in Cape Town, South Africa. International Journal of Educational Development, 28 340-347. http://dx.doi.org/10.1016/j.ijedudev.2007.05.007

Hayes, A.F. (2009). Beyond Baron and Kenny: Statistical mediation analysis in the new millennium. Communication Monographs, 76, 408-420. http://dx.doi. org/10.1080/03637750903310360

Hirschi, A. (2011). Callings in career: A typological approach to essential and optional components. Journal of Vocational Behavior, 79(1), 60-73. http://dx.doi. org/10.1016/j.jvb.2010.11.002

$\mathrm{Hu}$, L.T., \& Bentler, P.M. (1999). Cutoff criteria for fit indexes in covariance structure analysis: Conventional criteria versus new alternatives. Structural Equation Modeling: A Multidisciplinary Journal, 6, 1-55. http://dx.doi. org/10.1080/10705519909540118

Hunter, I., Dik, B.J., \& Banning, J.H. (2010). College students' perceptions of calling in work and life: A qualitative analysis. Journal of Vocational Behavior, 76, 178-186. http://dx.doi.org/10.1016/j.jvb.2009.10.008

Isaksen, J. (2000). Constructing meaning despite the drudgery of repetitive work. Journal of Humanistic Psychology, 40, 84-107. http://dx.doi.org/10.1177/ 0022167800403008

Jansen, J.D. (2007). If I were Minister of Education... Key priorities to turn public schooling around. In Paper presented at the first of a series of seminars of Umalusi, Pretoria, South Africa, August 2007.

Jerlinder, K., Danermark, B., \& Gill, P. (2010). Swedish primary-school teachers' attitudes to inclusion - The case of PE and pupils with physical disabilities. European Journal of Special Needs Education, 25, 45-57. http://dx.doi. org/10.1080/08856250903450830 
Jones, L.K. (1989). Measuring a three-dimensional construct of career indecision among college students: A revision of the vocational decision scale: The career decision profile. Journal of Counseling Psychology, 36, 477-486. http://dx.doi. decision profile. Journal of Couns
org/10.1037/0022-0167.36.4.477

Kuyini, A.B., \& Desai, I. (2007). Principals' and teachers' attitudes and knowledge of inclusive education as predictors of effective teaching practices in Ghana. Journal of Research in Special Educational Needs, 7(2), 104-113. http://dx.doi. org/10.1111/j.1471-3802.2007.00086.x

Lolwana, P. (2007). If I were Minister of Education... Key priorities to turn public schooling around. In Paper presented at the first of a series of seminars of Umalusi, Pretoria, South Africa, August 2007.

Lumadi, M.W. (2008). Teachers' exodus in South African schools: A smoke with burning fire. Contemporary Issue in Education Research - Third Quarter, 1(3), 31-40.

McKinsey \& Company. (2007). How the world's best performing school systems come out on top. Retrieved January 22, 2012, from http://www.mckinsey.com/ locations/UK_Ireland

Meijer, C.J.W., Soriano, V., \& Watkins, A. (Eds.) (2006). Provision in post-primary education. Odense, Denmark: European Agency for Development in Special Needs Education.

Motshekga, A. (2011). Focus schools. In Keynote address at SAOU Symposium on Focus Schools held at North West University, Potchefstroom, 15 October 2011. Potchefstroom, South Africa: Department of Basic Education.

MPlus [Computer software] (2011). Los Angeles, CA: Muthén \& Muthén.

Müller, K., Alliata, R., \& Benninghoff, F. (2009). Attracting and retaining teachers: A question of motivation. Educational Management Administration \& Leadership, 37, 574-599. http://dx.doi.org/10.1177/174114320933965

Nel, N., Müller, H., Hugo, A., Helldin, R., Bäckmann, Ö., Dwyer, H. et al. (2011). A comparative perspective on teacher attitude-constructs that impact on inclusive education in South Africa and Sweden. South African Journal of Education, 31, 74-90.

Nunnally, J.C., \& Bernstein, I.H. (1994). Psychometric theory. (3rd edn.). New York, NY: McGraw-Hill.

O'Brien, G.E. (1992). Changing meanings of work. In J.F. Hartley \& G.M. Stephenson (Eds.), Employment relations: The psychology of influence and control at work (pp. 44-66). Oxford, UK: Blackwell.

Pearson, S. (2007). Exploring inclusive education: Early steps for prospective secondary school teachers. British Journal of Special Education, 34(1), 25-32. http://dx.doi. org/10.1111/j.1467-8578.2007.00450.x

Rademeyer, A. (2013, 2 April). Onnies word nou dopgehou. Die Burger, p. 1.
Reinke, K., \& Moseley, C. (2002). The effects of teacher education on elementary and secondary preservice teachers' beliefs about integration: A longitudinal study. Action in Teacher Education, 24, 31-39. http://dx.doi.org/10.1080/01626620.20 Action in Teache
02.10463265

Rosso, B.D., Dekas, K.H., \& Wrzesniewski, A. (2010). On the meaning of work: A theoretical integration and review. Research in Organizational Behavior, 30 91-127. http://dx.doi.org/10.1016/j.riob.2010.09.001

Satorra, A., \& Bentler, P.M. (2010). Ensuring positiveness of the scaled difference chi-square test statistic. Psychometrika, 75, 243-248. http://dx.doi.org/10.1007/ s11336-009-9135-y

Silverman, J.C. (2007). Epistemological beliefs and attitudes toward inclusion in pre-service teachers. Teacher Education and Special Education, 30(1), 42-51. http://dx.doi.org/10.1177/088840640703000105

SPSS for Windows [Computer software] (2011). Chicago, IL: SPSS Inc.

Steger, M.F., \& Dik, B.J. (2010). Work as meaning. In P.A. Linley, S. Harrington, \& N. Page (Eds.), Oxford handbook of positive psychology and work (pp. 131-142). UK: Oxford University Press.

Steger, M.F., Dik, B.J., \& Duffy, R.D. (2012). Measuring meaningful work: The work and meaning inventory (WAMI). Journal of Career Assessment, 20(3), 322-337. http:// dx.doi.org/10.1177/1069072711436160

Steger, M.F., Pickering, N.K., Shin, J.Y., \& Dik, B.J. (2010). Calling in work: Secular or sacred? Journal of Career Assessment, 18(1), 82-96. http://dx.doi. org/10.1177/1069072709350905

Talmor, R., Reiter, S., \& Feigin, N. (2005). Factors relating to regular education teacher burnout in inclusive education. European Journal of Special Needs Education, 2 215-229. http://dx.doi.org/10.1080/08856250500055735

TIP: Concepts. (2010). Attitudes. Retrieved September 11, 2011, from http://www. tep-online.info/lernen/attitude.html

Treadgold, R. (1999). Transcendent vocations: Their relationship to stress, depression, and clarity of self-concept. Journal of Humanistic Psychology, 39, 81-105. http:// dx.doi.org/10.1177/0022167899391010

Wang J., \& Wang, X. (2012). Structural equation modeling: Application using Mplus. Chichester, UK: Wiley.

Wrzesniewski, A., McCauley, C., Rozin, P., \& Schwartz, B. (1997). Jobs, careers, and callings: People's relations to their work. Journal of Research in Personality, 31, 21-33. http://dx.doi.org/10.1006/jrpe.1997.2162

Zimbardo, P.G., \& Leippe, M. (1991). The psychology of attitude change and social influence. New York, NY: McGraw-Hill. 